\title{
EFFECTS OF SENSORY DEPRIVATION ON THE DEVELOPING MOUSE OLFACTORY SYSTEM: A LIGHT AND ELECTRON MICROSCOPIC, MORPHOMETRIC ANALYSIS ${ }^{1}$
}

\author{
THANE E. BENSON, ${ }^{*, 2}$ DAVID K. RYUGO, $\ddagger$ AND JAMES W. HINDS* \\ * Department of Anatomy, Boston University School of Medicine, Boston, Massachusetts 02118 and $\ddagger$ Department of Anatomy, \\ Harvard Medical School, Boton, Massachusetts 02115 and Eaton-Peabody Laboratory, Massachusetts Eye and Ear Infirmary, \\ Boston, Massachusetts 02114
}

Received April 19, 1983; Revised August 8, 1983; Accepted September 2, 1983

\begin{abstract}
Closure of the nostril by electrocauterization on postnatal day (PN) 1 or 2 was used to study effects of olfactory deprivation on developing olfactory epithelium $(\mathrm{OE})$ and bulb $(\mathrm{OB})$ in $\mathrm{CD}-1$ mice. No damage was observed in $\mathrm{OE}$ sections 1 or 3 days after closure, and at PN 30 no difference was found in the number of $\mathrm{OE}$ receptors between closed and open sides. Odor deprivation and a decrease in functional activity in experimental bulbs was evident from deoxyglucose autoradiographs at PN 21 and PN 30.

At PN 30 deprived bulbs appeared smaller than nondeprived bulbs. Nissl stains revealed normal cytoarchitecture, but a protargol stain demonstrated fewer intraglomerular dendrites in deprived bulbs. At PN 30 , volumes of deprived bulbs were $26 \%$ smaller than nondeprived bulbs. The volume of each bulbar lamina was 13 to $35 \%$ smaller than the comparable nondeprived lamina except for the ventricular/subependymal zone which was not significantly different between bulbs. Volumes of bulbs contralateral to the closed naris and the volumes of their laminae were not significantly different from control bulbs, suggesting no hypertrophy of nondeprived laminae.

Deprivation did not affect the number of mitral cells seen at PN 30, their nuclear size, or their number of nucleoli. Lateral olfactory tract cross-sectional area was also unaffected by deprivation. Mitral cell perikaryal size, however, was smaller in deprived bulbs. Soma surface areal density of deprived mitral-to-granule cell synapses in deprived bulbs was $65 \%$ of the nondeprived density, while the density of granule-to-mitral cell synapses was only $46 \%$ of the nondeprived density.

It is concluded that neonatal naris closure brings about a functional deprivation of the $\mathrm{OB}$ without receptor degeneration. Neonatal olfactory deprivation affects the perikaryal surface area but not the number of mitral cells. Also, deprivation markedly affects the reciprocal synapses between mitral and granule cells. Olfactory sensation thus appears necessary for normal development of $\mathrm{OB}$ neurons and synapses.
\end{abstract}

Compared to the studies on the visual, auditory, and somatosensory systems, relatively little work has been done on the effects of sensory impairment on the development of the olfactory system. Neonatal closure of the nostril has been reported to impede the postnatal increase in the size and weight of the ipsilateral olfactory

\footnotetext{
${ }^{1}$ This work was supported by University of Vermont Grant PHS 5429-40 to D. K. R. and United States Public Health Service Research Grant AG-00001. 'T. E. B. would like to thank his colleagues at the University of Vermont College of Medicine, Boston University School of Medicine, and the Mallory Institute of Pathology for the use of their facilities and helpful advice. We also wish to express our appreciation to Professor Gordon M. Shepherd and Drs. Pawel Jastreboff, Charles Greer, and Robert Williams for their valuable suggestions. For their
}

bulb in rabbits (Gudden, 1870) and rats (Meisami, 1976). Biochemical analyses have shown that the postnatal increases in total bulbar protein, DNA, RNA, AChE, and sodium-potassium ATPase are also impaired by neonatal naris closure (Meisami and Mousavi, 1981). In a quantitative anatomical study Meisami and Safari (1981)

excellent secretarial assistance we thank Ms. Janet Harry, Ms. Shirley Kelley, and Mr. Alfred Mueller. This work was submitted in partial fulfillment of the requirements for the Doctor of Philosophy in Anatomy (T. E. B.), Boston University Graduate School, Boston, Massachusetts 02215 .

${ }^{2}$ To whom correspondence should be addressed at Section of Neuroanatomy, Yale University School of Medicine, 333 Cedar Street, New Haven, CT 06510. 
reported that the relative dimensions of the olfactory bulb and some of its laminae on the side ipsilateral to the closed naris are small compared to those contralateral. In addition, they reported that olfactory glomerulus size and number were not affected by naris closure. The numbers of superficial and middle tufted cells and mitral cells were significantly reduced, although the diameters of the latter cells were apparently unaffected.

The effects of neonatal naris closure on the olfactory epithelium have not been reported. Frühwald (1935) examined the nasal fossae of rabbits sacrificed 12 and 14 weeks following surgical naris closure at weaning. $\mathrm{He}$ described patchy degeneration of the respiratory and olfactory epithelia with atrophy of olfactory nerve fascicles and Bowman's glands on the side of naris closure. However, since Frühwald apparently did not follow sterile procedures during his surgical naris closures, and he did not give his rabbits antibiotics afterward, these changes may reflect rhinitis and not sensory deprivation (Smith, 1937).

In the present study we have analyzed effects of neonatal naris closure in CD-1 mice. To determine if these effects are due to immediate trauma, qualitative assessment of the nasal fossa was made at short survival times. The olfactory receptors at 30 postnatal days were analyzed quantitatively to see if a relative change in their number might be correlated with any change in the olfactory bulb at that age. Deoxyglucose autoradiography was employed to determine if naris closure functionally deprives the ipsilateral olfactory bulb.

Qualitative and volumetric analyses of the olfactory bulb and its six laminae were carried out on postnatal day 30 . In addition, some of the morphological properties of mitral cells, a bulbar projection neuron postsynaptic to olfactory receptor axons, were measured.

Finally, effects of naris closure on the synapses between mitral cells and anaxonic interneurons of the olfactory bulb, granule cells, were quantified by stereological analysis.

\section{Materials and Methods}

CD-1 mice (Charles River Breeding Laboratories) were kept in a room with a 12-hr light-dark cycle and had access to food and water ad libitum. The presence of rhinitis in experimental and control animals was assessed by the size and appearance of the olfactory nerve layer and olfactory glomeruli in the olfactory bulb and by the appearance of the olfactory epithelium on selected sections of the nasal septum or in whole nasal cavities (Smith, 1935, 1937). As far as could be determined, no rhinitic animals were used in this study. On the day of birth or one day thereafter (PN 1 or 2) litters were removed from the nest and culled to eight pups. Usually, five pups were randomly chosen as experimental animals, and their left or right naris was closed by cauterization with an electrocautery unit (Meisami, 1976). The remaining three pups (controls) were placed back in the nest with their experimental littermates. Animals with either incomplete naris closure or excessive cauterizations involving the contralateral naris were discarded.

To assess the acute effects of naris cauterization on the olfactory epithelium, two pups were killed the day following the procedure along with a control littermate. One experimental pup was killed 3 days following cauterization. Heads were prepared by Paraplast embedding, sectioned horizontally at $4 \mu \mathrm{m}$ thickness, and selected sections were stained by the protargol method (Bodian, 1936).

Olfactory receptors. Ten 30-day-old experimental and three control animals were used to determine the effect of naris closure on the rostral or ventral extent of the olfactory epithelium on each side of the nasal septum. From this group, six series of horizontal sections of the nasal cavity and seven series of coronal sections of the nasal septum or cavity were prepared and used for quantification. The differences between the two sides in the rostral or ventral position of the transition zone from olfactory to respiratory epithelium were measured with a calibrated reticule at $\times 160$. The available whole nasal cavities $(n=7)$ in this data group were also assessed qualitatively.

To determine if there was an effect of neonatal naris closure on the density of mature olfactory receptors at PN 30, olfactory receptor knobs were counted in three, comparable, $1-\mu \mathrm{m}$ coronal sections of the nasal septum from each of four experimental animals. Data sections were separated from each other by $1 \mathrm{~mm}$. Olfactory receptor knobs, rather than the nuclei of neural elements in the epithelium, were counted because knobs represent mature, or nearly mature, receptors (Kerjaschki and Hörandner, 1976). In contrast, neuronal nuclei in the epithelium can belong to cells in quite different stages of differentiation (Graziadei and Monti Graziadei, 1979), and the proportion of nuclei belonging to cells at a given stage of maturity can vary (Monti Graziadei et al., 1980).

Maps were made of the $1-\mu \mathrm{m}$ data sections at a magnification of $\times 175$ using a drawing tube. Then, at a higher magnification $(\times 63$, oil objective) receptor knobs having a connection with the epithelium were counted (see Fig. 1). Counting began at a region near the dorsal recess and proceeded to the ventral extent of the olfactory epithelium. The absolute length along which knobs were counted was determined on the previously constructed map with a Zeiss MOP 3 digital image analysis system. The mean number of knobs per millimeter was calculated for each side of the septum from each of the four animals. These four pairs of numbers were analyzed by a paired $t$ test.

Olfactory bulb function. Four experimental pups, two at 21 and two at 30 postnatal days, were prepared for $\left[{ }^{3} \mathrm{H}\right]$ deoxyglucose autoradiography. Two microcuries per gram of body weight of reconstituted tracer (specific activity $40 \mathrm{Ci} / \mathrm{mmol}$ ) were injected intraperitoneally, and the experimental animal was placed in a covered cage with soiled home-cage shavings for 45 min. Perfusion, subsequent processing, and autoradiography proceeded as outlined by Stryker (1979) and Hand (1979).

Olfactory bulb morphology and cytology. Olfactory bulb sections from 30-day-old control $(n=3)$ and experimental $(n=4)$ animals were processed by the Bodian (1936) method. Paraplast and Araldite embedded bulb sections stained with cresyl violet or toluidine blue were also used for qualitative assessment.

Olfactory bulb volumes. For the determination of whole 


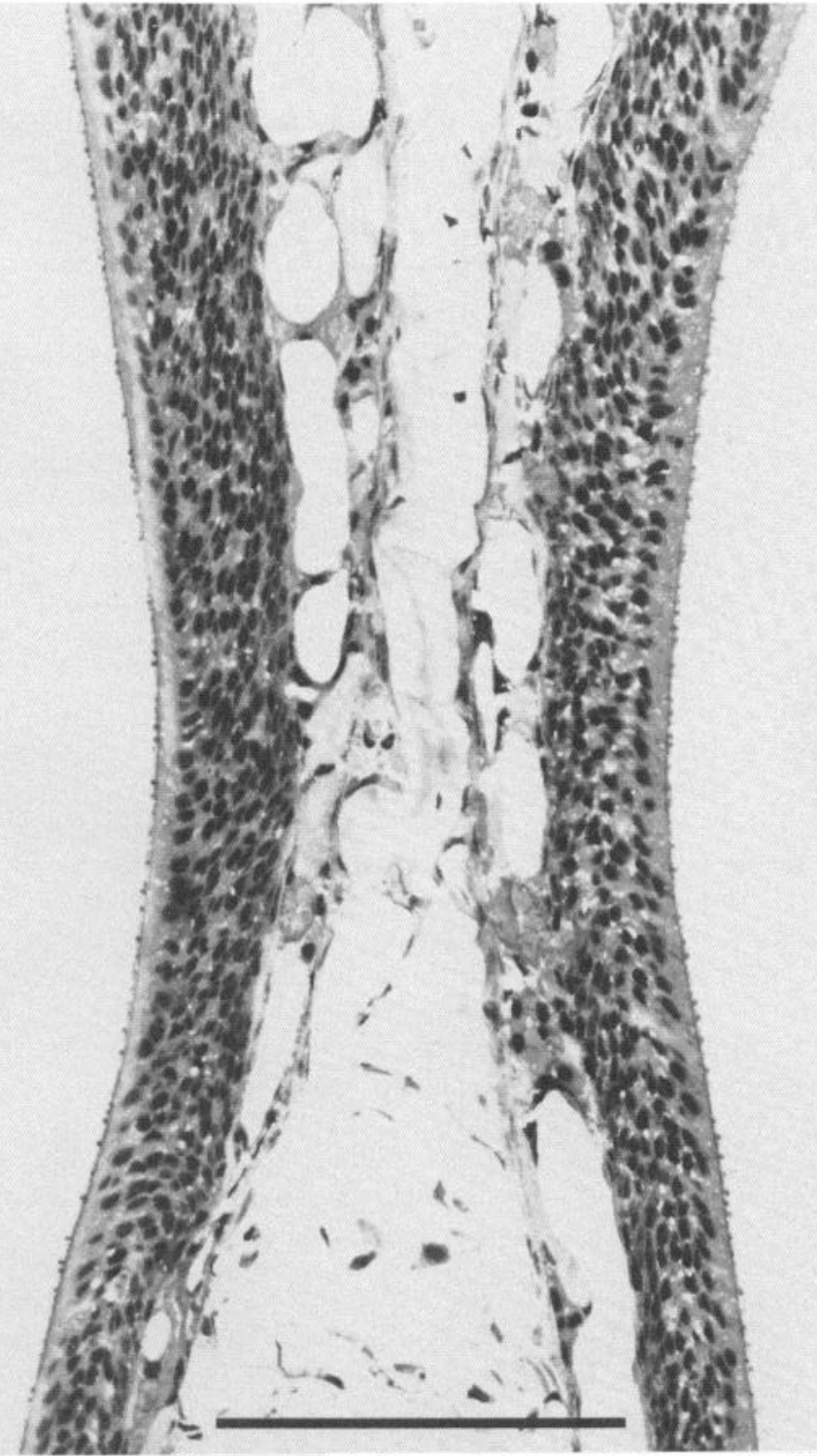

Figure 1. Olfactory epithelium on the nasal septum fixed by two-stage perfusion (Peters, 1970) and used to count receptor knobs. Note that although fixation is not optimal, receptor knobs on the luminal surface are very apparent. The closed side is on the right. One-micrometer coronal section, toluidine blue stain. Bar $=0.1 \mathrm{~mm}$.

olfactory bulb and laminae volumes, brains of seven experimental and six 30-day-old control animals were prepared by Paraplast embedding and horizontal sectioning. The entire olfactory bulb was semiserially sampled. Section thickness was 10 or $8 \mu \mathrm{m}$. Mounted sections were stained with cresyl violet. Magnified images of the olfactory bulb and bulbar laminae were traced, and the volumes of the constituent laminae and total bulbar volume were calculated (uncorrected for shrinkage). Paired $t$ tests were performed on the total bulb volume data to compare the six left and right control bulbs and compare the seven bulbs from the closed sides to the open sides in the experimental animals. Unpaired $t$ tests were used to analyze the difference between left control and closedside bulbs and between left control and open-side bulbs. Paired and unpaired $t$ tests making the same comparisons as those made between the total bulb data were also performed for each bulbar lamina. Because each bulb has six constituent laminae, six $t$ tests were run for each comparison. To minimize type II statistical error, the experiment-wise error rate (Steel, 1961) was used. An analysis of variance was performed to determine if there was a difference in the degree of experimental effect between litters. An analysis of variance was also used to determine if the bulbar laminae of the experimental animals were affected differentially by naris closure, and a Tukey B a posteriori test (Winer, 1962) was used to determine which, if any, laminae were affected by naris closure to a greater degree than the other laminae.

Mitral cell morphometry. Four 30-day-old experimental animals were used to determine the effects of naris closure on mitral cell nuclear size, number, and relative number of nucleoli. Semiserial 1- $\mu \mathrm{m}$ coronal sections of the entire olfactory bulb were employed. From comparable sections, all mitral cell nuclei were drawn with the aid of a drawing tube at $\times 630$. A total of 941 cells from closed sides and 837 from open sides were drawn. The absolute areas of each nuclear profile were determined

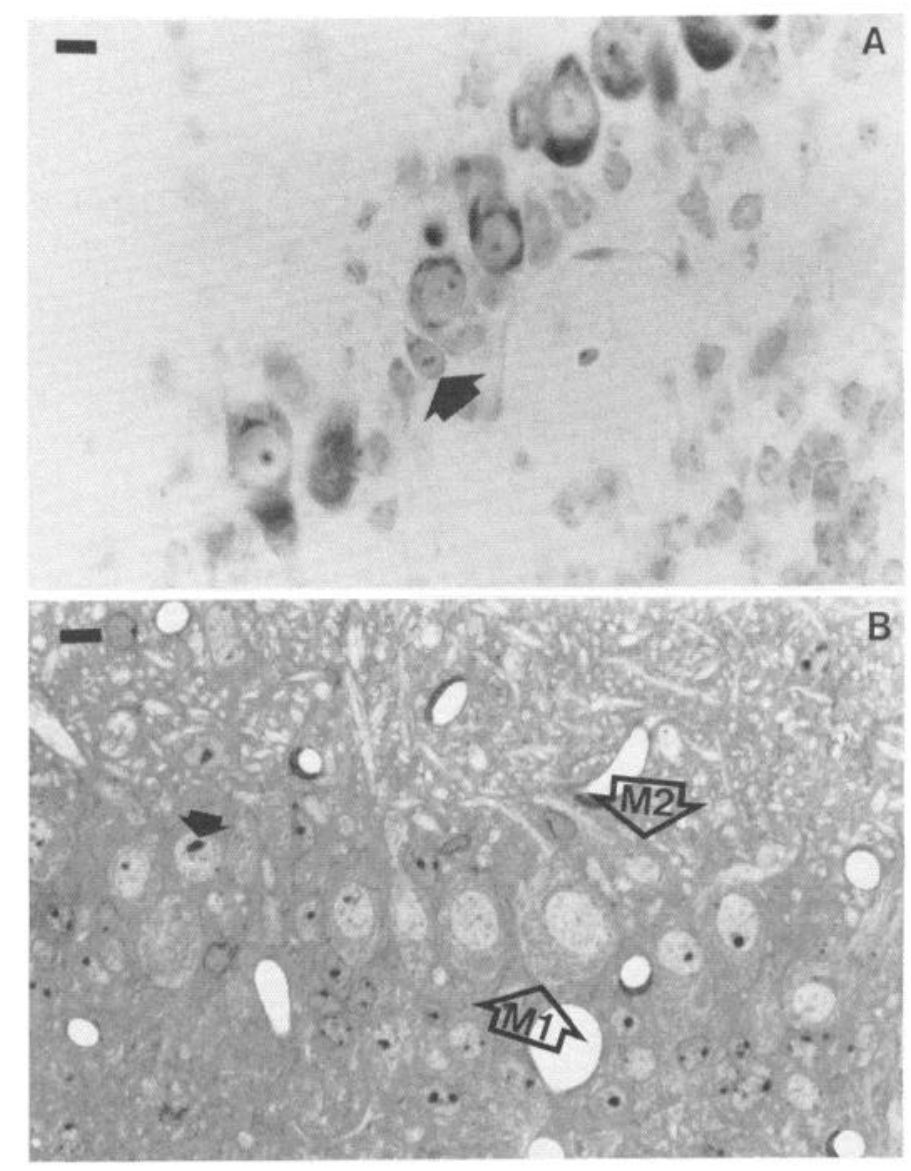

Figure 2. A, Mitral cells from a paraffin section which was used for the determination of olfactory bulb volumes (open side). Note that although the cellular fixation and staining is good, the identification of one intermediate-sized cell (arrow) is not clear. Ten-micrometer section, cresyl violet stain. Bar = $10.0 \mu \mathrm{m}$. B , Plastic embedded mitral cells of the type used for counting, size determination, and electron microscopy (closed side). Note the tigroid Nissl substance, pale nucleus, and the boundaries of the cells and their nuclei. A large (M1) and a small ( M2) mitral cell are indicated, as is a nucleolus (arrow). One-micrometer sections, toluidine blue stain. Bar $=10.0 \mu \mathrm{m}$. 
with a Zeiss MOP 3, and a mean profile area was calculated for each side of each animal. Treating these mean areas as those of a circle, a mean radius was calculated. The height of the nuclear cap invisible because of insufficient contrast (the "lost" cap) was determined to be $0.15 \mu \mathrm{m}$. Using this value, the mean radius of the sectioned nuclei, and the known section thickness $(1 \mu \mathrm{m})$, a measure of the true radius of mitral cell nuclei for each of the eight olfactory bulbs was calculated (Freedman, 1974). Detailed justification of this procedure can be found in Hinds and McNelly (1977).

Mitral cells were counted from sections taken at selected intervals as described by Hinds and McNelly (1977). Profiles with different numbers of nucleoli (zero to five) were counted separately. Mitral cells were iden- tified by cytological characteristics such as their pale, round nucleus, obvious cytoplasmic surround, and Nissl bodies. These characteristics have been described in studies using either the light (Ramón y Cajal, 1911) or electron microscope (Price and Powell, 1970). However, it was determined in a preliminary analysis that there was some ambiguity in the identification of small mitral cells in 8- or 10- $\mu \mathrm{m}$ paraffin sections as opposed to $1-\mu \mathrm{m}$ sections (see Fig. 2). For each olfactory bulb of the four experimental animals the number of mitral cells was corrected by the Floderus (1944) equation. In addition, the number of nucleoli per $1-\mu \mathrm{m}$ section of mitral cell nucleus was calculated. Paired $t$ tests on closed and open sides were used to determine if observed differences in these mitral cell parameters were significant.

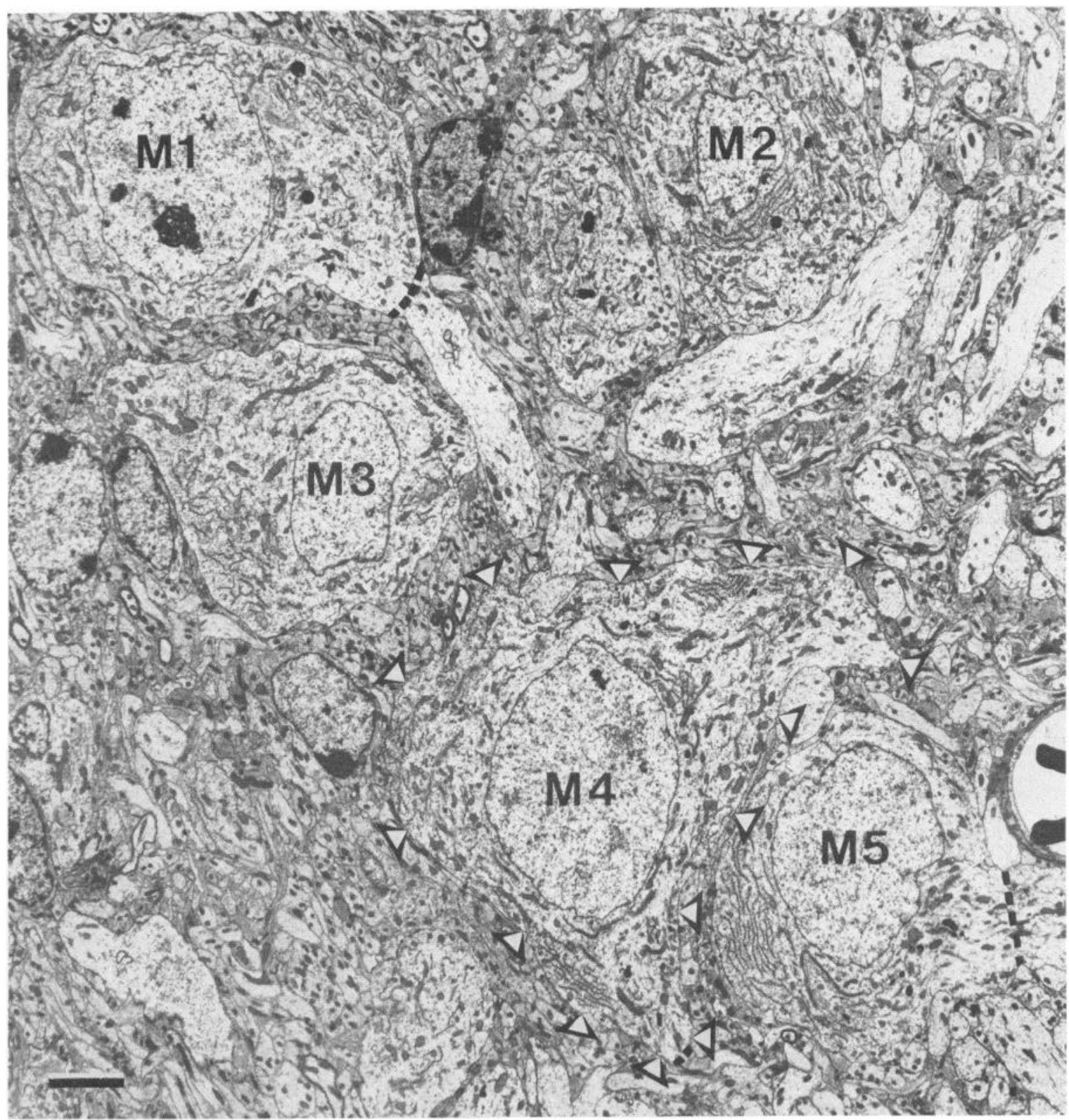

Figure 3. Electron micrograph used for the determination of soma surface area (open side). The cell membrane of one of the mitral cells (M4) is indicated with white arrowheads. Dendrites were truncated as indicated with dashed lines. Cells with small nuclear profiles, such as cell $M 2$, were included in the analysis. Approximately 90 -nm section; uranyl acetate, lead citrate stain. Bar $=5.0 \mu \mathrm{m}$. 
As an independent measure of the effect of naris closure on the number of projection neurons in the olfactory bulb at PN 30, the cross-sectional area of the lateral olfactory tract was measured. The lateral olfactory tract contains the efferent axons of these projection neurons, mitral and tufted cells (Haberly and Price, 1977; Scott, 1981; Schneider et al., 1982). To measure the crosssectional area of the tract, coronal, $1-\mu \mathrm{m}$ sections were taken at the level of the caudal portion of the anterior olfactory nucleus from four experimental animals. Most

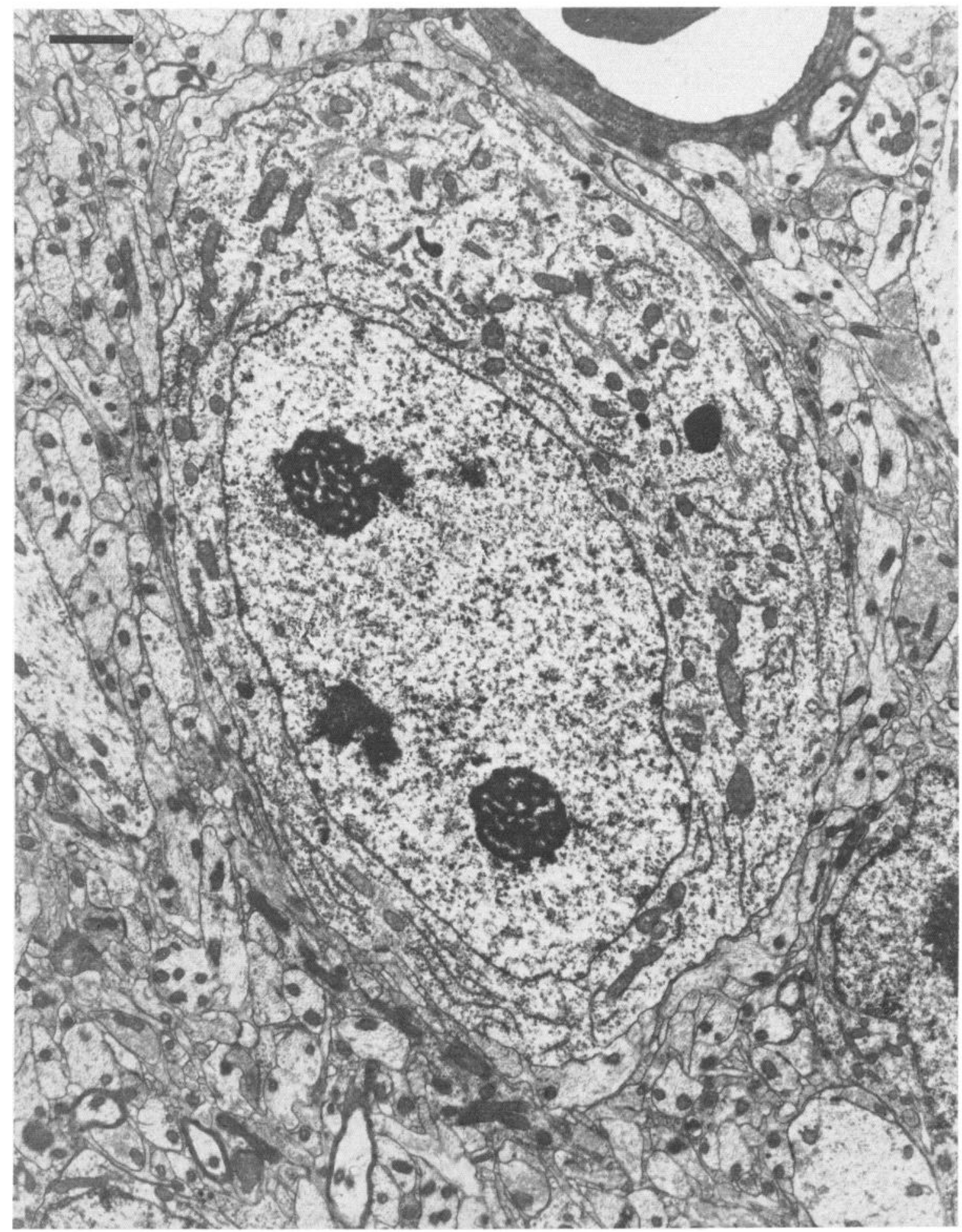

Figure 4. Electron micrograph of a mitral cell used for the determination of synapse densities (open side). Portions of three nucleoli are visible. Although numerous synapses are visible from and onto the soma (four mitral-to-granule and three granuleto-mitral synapses were counted for this cell), counts were made from the negative at much higher magnification. The image used for the measurement of soma membrane and postsynaptic density lengths was also printed at a higher magnification. Approximately 80-nm section; uranyl acetate, lead citrate stain. Bar $=2.0 \mu \mathrm{m}$. 
mitral and tufted cell axons have joined the tract by this point (Price and Sprich, 1975). So that the sections from the closed and open sides would be comparable, they were within $50 \mu \mathrm{m}$ of the point where myelinated fibers from the medial aspect of the olfactory bulb could no longer be seen coursing along the surface of the anterior olfactory nucleus, pars dorsalis. The outlines of the tract and large blood vessels therein were traced at $\times 140$, and the absolute value (in square millimeters) of each tract section (minus blood vessels) was determined with the MOP 3.

Mitral cell soma profile areas were measured in coronal 90-nm sections taken at the level of the rostral tip of the accessory olfactory bulb from four 30 -day-old experimental animals. Samples of 0.4 to $0.8 \mathrm{~mm}$ of the mitral cell layer from the lateral aspects of the bulbs were chosen because in this region the layer is relatively straight. Electron micrographs were printed at a magnification of $\times 4300$ to $\times 4500$. From these micrographs 158 cells from closed sides and 153 from open sides with nuclear profiles therein were measured. The dendrites of cells were truncated (Hinds and McNelly, 1977; see also Fig. 3), and the absolute area of each cell profile was measured with the MOP 3. A distribution of profile sizes was generated, and the significance of the difference between the distribu- tions from deprived and nondeprived sides was determined by a Kolmogorov-Smirnov test (Sokal and Rohlf, 1969).

We have made the assumption that by measuring mitral cells sectioned through the nucleus, our sample is limited to cells sectioned in an equatorial plane. Based on this assumption, the surface area of equivalent spheres was calculated from the means of the distributions of profile areas.

Synapse densities of mitral cell soma. Four 30-day-old experimental animals were used for the determination of the surface areal densities of synapses from and onto the somata of mitral cells. Sections were from the same ribbons used for the determination of mitral cell soma surface areas. Starting from the left or right side of a section the first 15 or 20 mitral cells with a nuclear profile were photographed (see Fig. 4). In all, 100 cells from closed sides and 83 from open sides were examined. Negatives were coded so that the researcher performing the analysis (T. E. B.) could not determine, a priori, from which side a cell was located.

Synapses were identified at a final magnification of $\times 75,000$. The criteria for the identification of a synapse included; a parallel apposition of membranes, a postsynaptic density and/or presynaptic dense projection(s), and

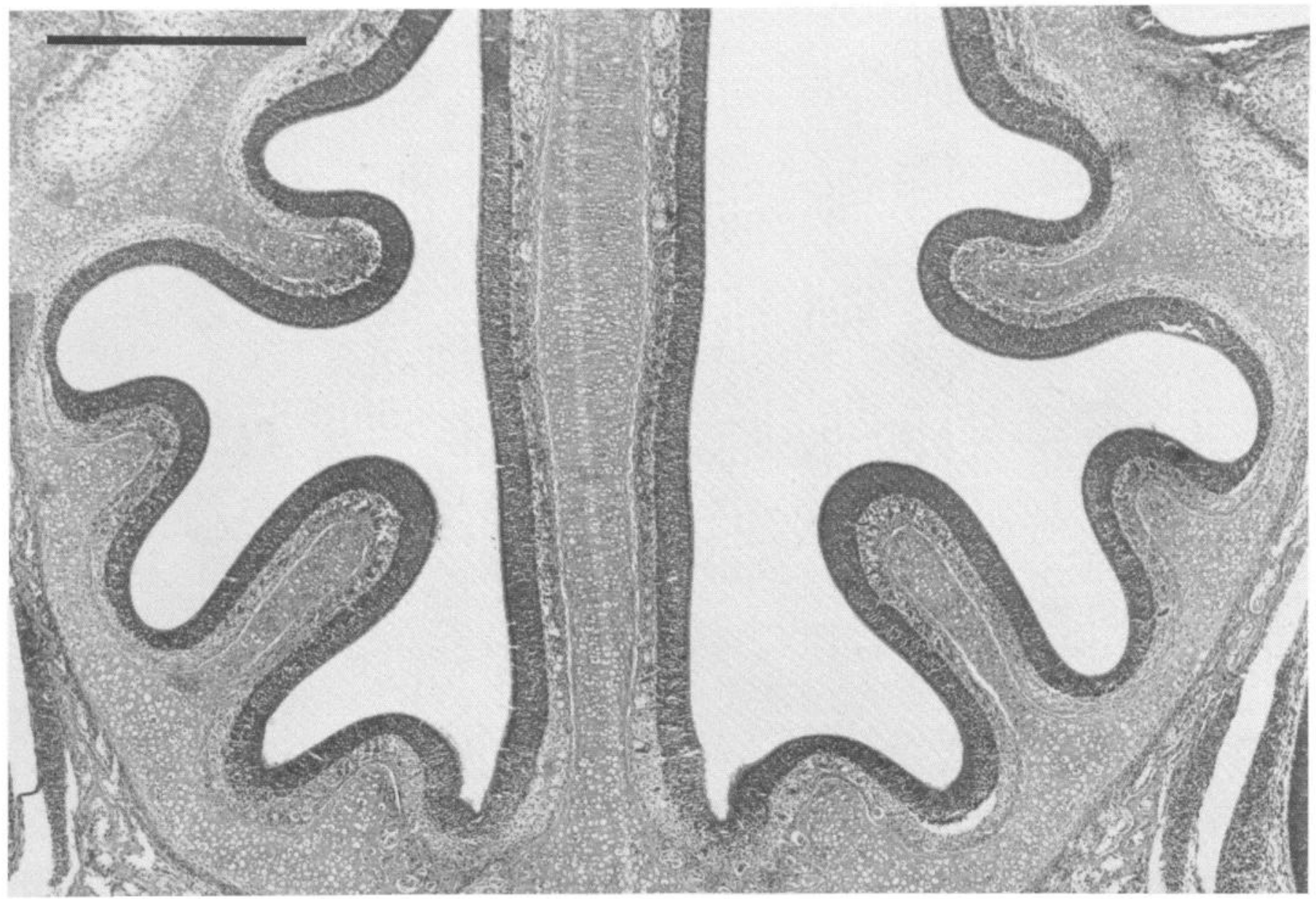

Figure 5. Light micrograph of a horizontal section through the nasal cavity of an experimental animal 3 days after naris closure. The side of naris closure is on the right. The lumen appears smaller in this section, but no gross sloughing of the receptor epithelium or other indications of trauma due to cauterization are apparent. Four-micrometer section; Bodian's protargol stain. Bar $=0.5 \mathrm{~mm}$. 
a close approximation between the presynaptic membrane and at least one synaptic vesicle. The polarity (mitral-to-granule or granule-to-mitral) of identified synapses was noted. The absolute lengths of soma membranes (dendrites were truncated) and of each synaptic membrane density were measured with the MOP 3 on the print of each cell examined. The mean lengths of the two types of synaptic densities, the total length of membrane examined, and the number of synapses of each type per length of membrane were calculated for each olfactory bulb. A total of 217 mitral-to-granule synapses were counted on the closed sides and 283 on the open sides; 152 granule-to-mitral synapses were counted on the closed sides and 280 on the open sides. A total of $5184 \mu \mathrm{m}$ of membrane from the closed sides and 4474 $\mu \mathrm{m}$ from the cells of the open sides was examined. The surface areal densities of synapses from or onto the somata of mitral cells for each olfactory bulb were calculated as described by Mayhew (1979), as were the number of synapses of each type per soma. Paired $t$ tests of closed and open sides were used to determine if the observed differences in postsynaptic density lengths and synapse surface areal densities were significant. In ad- dition, an analysis of variance was used to determine if the ratio given by the number of mitral-to-granule cell synapses per soma divided by the number of granule-tomitral cell synapses per soma was significantly different between the closed and open sides.

\section{Results}

Acute effects on the olfactory epithelium. It was apparent that electrocauterization of an external naris did not traumatize the olfactory epithelium. Neither the two experimental animals which were killed the day following naris cauterization nor the one killed 3 days following cauterization showed pathology of the olfactory epithelium (see Fig. 5). The nasal fossae were clear of debris and white blood cells. Although no quantitative analysis of the olfactory epithelium was undertaken, the thickness of the epithelium and its extent rostrally on the nasal septum and on the turbinate bones appeared the same on both sides.

Olfactory receptor number. There was no obvious asymmetry in the extent of olfactory epithelium on the two sides of the nasal septum due to the experimental closure. Measurements of the rostral $(n=5)$ and ventral $(n=5)$

\section{P21}

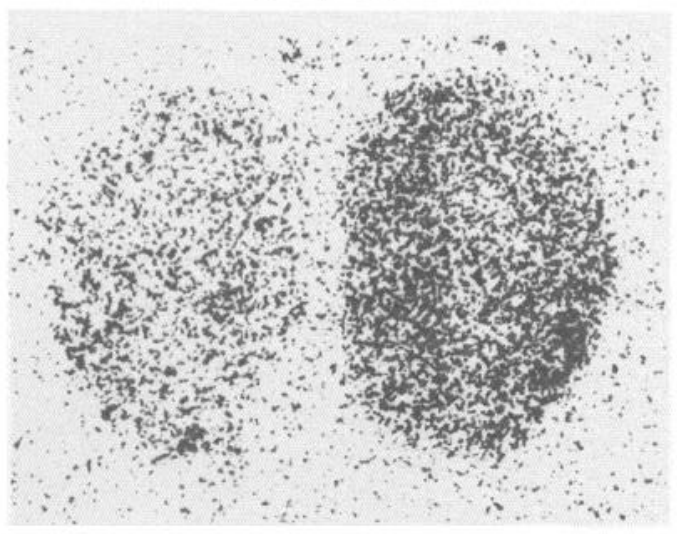

D ND

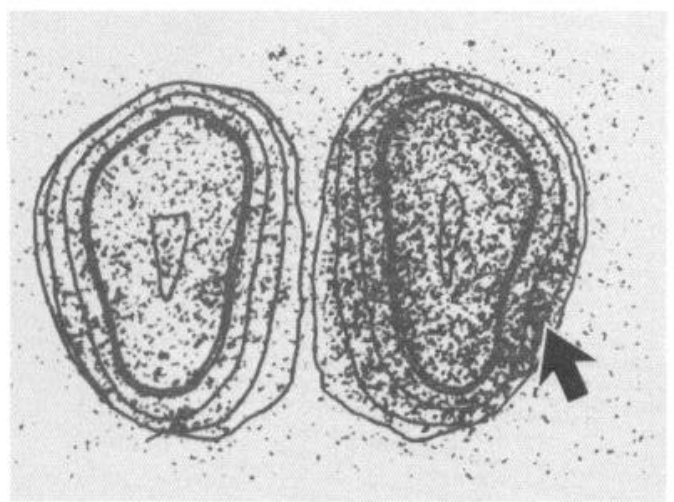

P30

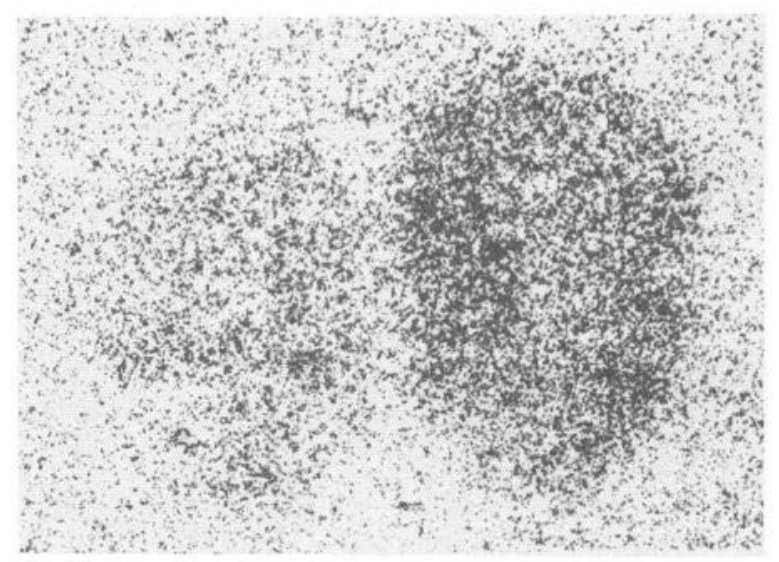

D ND

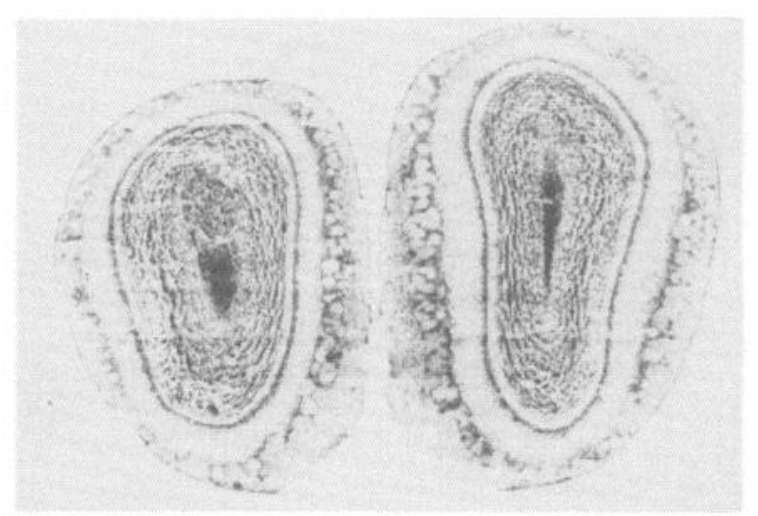

Figure 6. Autoradiographs from two experimental animals that were injected with $\left[{ }^{3} \mathrm{H}\right]$-2-deoxyglucose, one on postnatal day $21(P 21)$, the other on postnatal day $30(P 30)$. The olfactory bulb laminae have been superimposed on the autoradiographic image from the 21-day animal, and a focus of deoxyglucose uptake is indicated (arrow) in the glomerular layer of the open side in that animal. A photomicrograph of the cryostat section from which the autoradiograph was made is presented for the 30 -day animal. $D$, deprived (closed) side; $N D$, nondeprived (open) side. Twenty-micrometer section; cresyl violet stain. Magnification $\times$ 20 . 

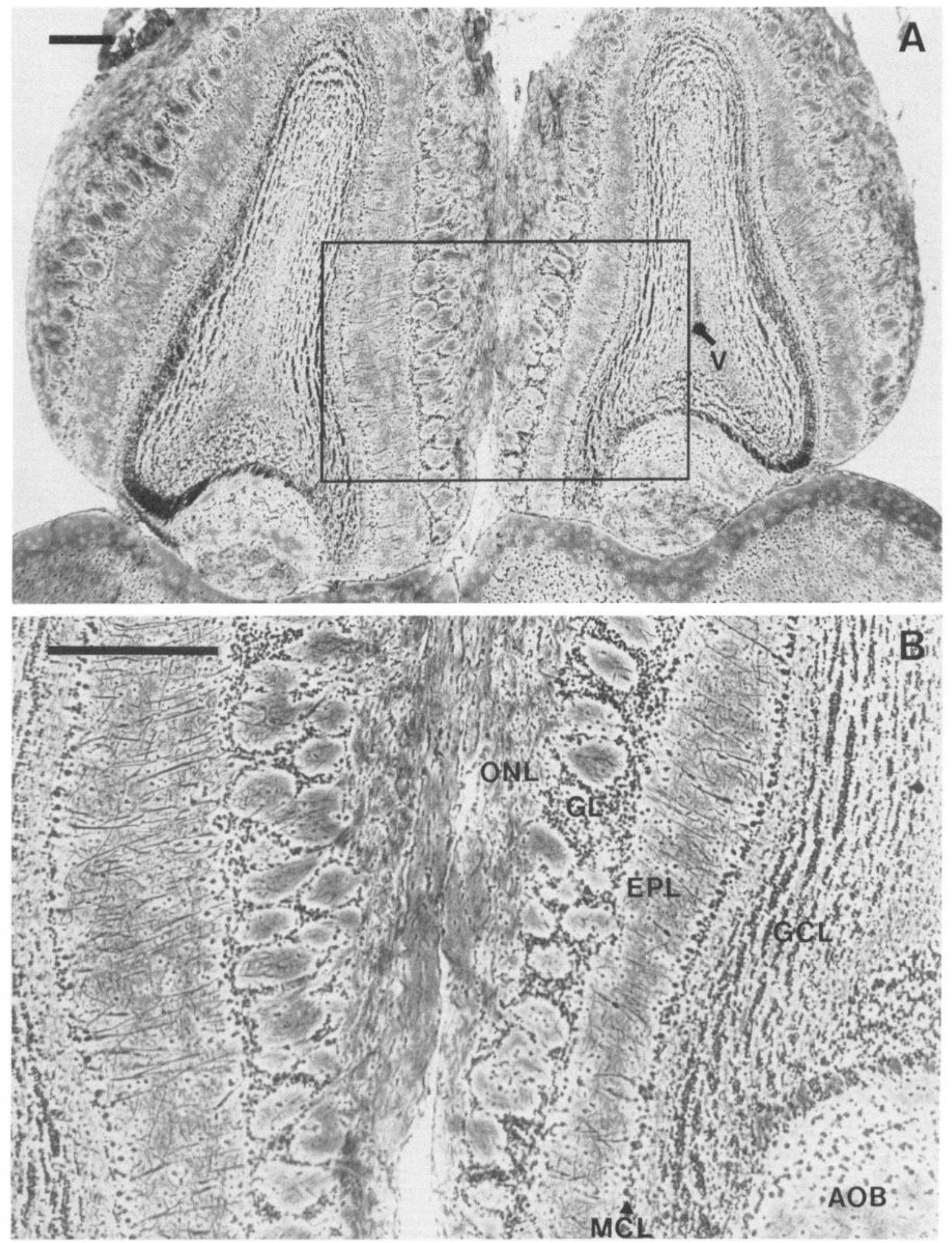

Figure 7. A, Horizontal section of the olfactory bulbs and rostral neocortex of an experimental mouse. Note the smaller size of the bulb on the deprived side (right) and the rostral outpouching of the neocortex on that side. $V$, ventricular/subependymal zone. Ten-micrometer section; Bodian's protargol stain. Bar $=0.25 \mathrm{~mm}$. B, Higher magnification of the region enclosed by the box. The smaller width of the external plexiform $(E P L)$ and glomerular $(G L)$ layers is apparent. Radially oriented primary dendrites of mitral and tufted cells are visible in the EPL. Note the difference in the complexity of the stained neuropil, especially in the glomerular layer. $O N L$, olfactory nerve layer; $M C L$, mitral cell layer; $G C L$, granule cell layer; $A O B$, accessory olfactory bulb. Bar $=0.25 \mathrm{~mm}$. 
extents of the epithelium at PN 30 showed that in the experimental population, the differences in these measurements were small (usually less than $100 \mu \mathrm{m}$ ), and there was no systematic relation to the closed side. These measurements were also indistinguishable from those of controls $(n=3)$. To the extent that the septal mucosa is representative, these results suggest that naris closure had no significant effect on the surface area of the olfactory epithelium. In addition, the extent and thickness of the olfactory epithelium on the turbinate bones and recesses appeared equivalent on the closed and open sides of all nasal cavities examined $(n=7)$.

At PN 30 the morphology of the olfactory epithelium from the closed side appeared normal. No significant difference was found in the relative numbers of receptor knobs between the closed and open sides. There was a mean of $249 \pm 4$ ( \pm standard error of the mean) knobs/ $\mathrm{mm}$ on the open side and $245 \pm 10 \mathrm{knobs} / \mathrm{mm}$ on the closed side $(n=4 ; p=0.68)$. Taken together with the finding that the extent and thickness of the olfactory epithelium on the nasal septum and in the nasal cavity appeared equivalent in both nasal fossae of experimental animals, this suggests that the number of mature olfactory receptors at PN 30 is not affected by neonatal naris closure.

Olfactory bulb function. The olfactory bulbs of the closed sides were functionally deprived. In each of the four animals studied with the deoxyglucose technique there was considerably less uptake of the tracer in the olfactory bulbs on the closed side as indicated by the autoradiographic images (see Fig. 6). The amount of radioactivity in the closed side bulbs was above extra tissue background, but noticeably less than that in the open side bulbs. Foci of deoxyglucose uptake were noted on the open sides, especially in the glomerular layer, as previously reported in rats exposed to cage odors (Stewart et al., 1979). In contrast, such sites of focal tracer uptake were not observed in bulbs of closed sides.

Olfactory bulb morphology and cytology. The deprived olfactory bulbs of 30-day-old experimental animals were conspicuously smaller than nondeprived bulbs. In Bodian- and Nissl-stained horizontal sections, differences in the sizes of the deprived and contralateral bulbs and bulbar laminae, and a rostral outpouching of portions of the paleopallium and neopallium on the deprived side were apparent (see Figs. 7A and 8). The overall morphology of deprived bulbs appeared similar to that of control bulbs. However, the protargol-stained neuropil of deprived glomeruli appeared less complex than that of contralateral ones (see Fig. $7 B$ ). The ventricular/subependymal zone also appeared larger on the deprived sides.

Olfactory bulb volumes. At PN 30, in the seven animals measured, the mean volume of the deprived olfactory bulbs, $4.26 \pm 0.25 \mathrm{~mm}^{3}$, was smaller than that of the nondeprived bulbs, $5.73 \pm 0.17 \mathrm{~mm}^{3}(p<0.001)$. The mean volume of the left control bulbs, $5.57 \pm 0.06 \mathrm{~mm}^{3}$ $(n=6)$, was greater than that of the deprived bulbs ( $p$ $<0.001$ ) and not significantly different from that of the nondeprived bulbs $(p=0.44)$ or the right control bulbs, $5.52 \pm 0.11 \mathrm{~mm}^{3}(p=0.53)$.

Mean laminar volumes for the deprived and contralat-

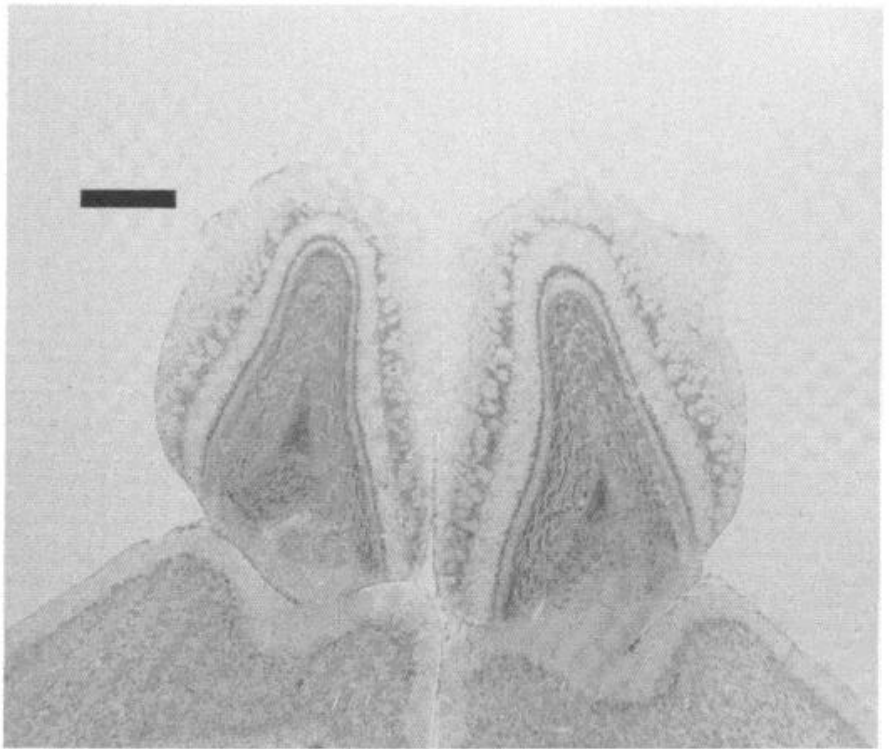

Figure 8. Horizontal section of the olfactory bulbs and rostral neocortex of an experimental mouse. Although the deprived bulb (left) is smaller, its lamination appears normal (designations of laminae presented in Fig. 9). The morphology of the laminae is also apparently normal. For example, glomeruli are apparent in the glomerular layer, and in the granule cell layer the granule cells are grouped in characteristic "islands." Tenmicrometer section; cresyl violet stain. Bar $=0.5 \mathrm{~mm}$.

TABLE I

Laminar mean volumes \pm standard error in cubic millimeters for deprived and nondeprived olfactory bulbs

\begin{tabular}{lcc}
\hline \multicolumn{1}{c}{ Lamina } & Deprived & Nondeprived \\
\hline Olfactory nerve layer & $1.02 \pm 0.039$ & $1.17 \pm 0.055$ \\
Glomerular layer & $0.88 \pm 0.066$ & $1.16 \pm 0.046$ \\
External plexiform layer & $0.88 \pm 0.086$ & $1.37 \pm 0.040$ \\
Mitral cell layer & $0.16 \pm 0.010$ & $0.20 \pm 0.007$ \\
Granule cell layer & $1.27 \pm 0.078$ & $1.79 \pm 0.078$ \\
Ventricular/subependymal & $0.05 \pm 0.002$ & $0.04 \pm 0.002$ \\
$\quad$ zone & & \\
\hline
\end{tabular}

eral bulbs are presented in Table I. The mean volume of each lamina from the deprived olfactory bulbs was smaller than that from the nondeprived except for the volume of the ventricular/subependymal zone, which was larger on the deprived sides, but not significantly so. The mean volumes of the nondeprived laminae were not significantly different from those of the left control bulbs. A graphic representation of these two comparisons is given in Figure 9, as are the $p$ values for the comparisons. There was no significant difference between the mean volumes of the laminae in the left and right control olfactory bulbs. These results are presented in Table II.

Olfactory deprivation affected bulbar laminae to different degrees as indicated by a $p$ value less than 0.001 in the analysis of variance for this comparison. The Tukey B test confirmed that the ventricular/subependymal zone was affected by deprivation in a significantly different way from all the other layers $(p<0.05)$. This test also indicated that the volumes of the external plexiform and granule cell layers were more affected by deprivation than was the volume of the olfactory nerve layer $(p<0.05)$. 


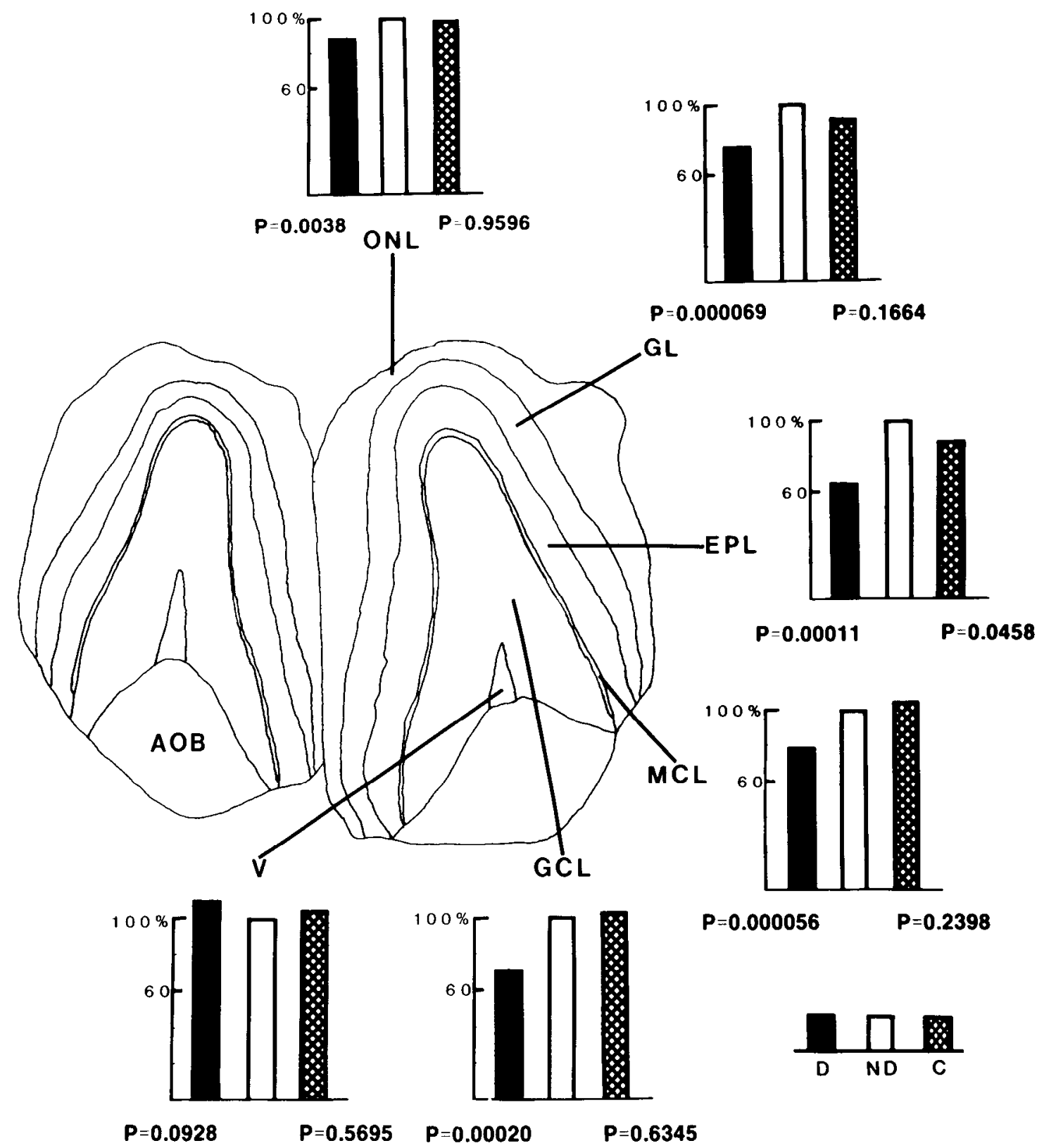

Figure 9. Tracing of a horizontal section (the section in Fig. 8) of the type used for the determination of laminar and bulbar volumes. In the graphs for each lamina, the mean volume of the nondeprived sides $(N D)$ is expressed as $100 \%$. The mean volume of the deprived sides $(D)$ is expressed as the ratio $\mathrm{D} / \mathrm{ND}$. The mean volume of the left control sides $(C)$ is expressed as the ratio $\mathrm{C} / \mathrm{ND}$. The $p$ values are the results of paired $t$ tests $(n=7)$ on the deprived and nondeprived volumes and unpaired $t$ tests ( $n=6$ and 7) on the left control and nondeprived volumes. The $p$ values must be less than 0.0085 for an experiment-wise significance of less than 0.05 . $O N L$, olfactory nerve layer; $G L$, glomerular layer; $E P L$, external plexiform layer; $M C L$, mitral cell layer; $G C L$, granule cell layer; $V$, ventricular/ subependymal zone; $A O B$, accessory olfactory bulb.

The between-litter analysis of variance on the ratios of total olfactory bulb volumes gave a $p$ value of less than 0.001 , indicating that there was a difference in the degree of the experimental effect between litters. However, analyses of variance could not detect a difference in the degree of the experimental effect across litters for individual laminae (see Table III).

Mitral cell measurements. Neither mitral cell nuclear radius, the number of nucleoli per nuclear profile, nor the number of mitral cells per olfactory bulb were af- fected by deprivation as measured at PN 30 in four experimental animals (see Table IV). In addition, the cross-sectional area of the lateral olfactory tract was not affected by deprivation (see Table IV), and the tracts were normal in appearance. Although individual axons in the lateral olfactory tract were not counted, these latter two findings would seem to corroborate the finding of no significant difference in the number of mitral cells. The comparison of mitral cell perikaryal sizes (profile areas in electron micrographs) revealed a significant 
difference $(p<0.001$, see Fig. 10). The mean surface area of deprived mitral cells was calculated to be 646 $\mu \mathrm{m}^{2}$; that of nondeprived mitral cells was $718 \mu \mathrm{m}^{2}$.

Synapses. As determined from four 30-day-old experimental animals, postsynaptic density length was not affected by deprivation. The mean length of mitral-togranule cell synapse densities was $0.37 \pm 0.02 \mu \mathrm{m}$ on the deprived sides and $0.33 \pm 0.01 \mu \mathrm{m}$ on the nondeprived sides $(p=0.18)$. The mean length of granule-to-mitral cell postsynaptic densities was $0.44 \pm 0.02 \mu \mathrm{m}$ on the deprived sides and $0.40 \pm 0.01 \mu \mathrm{m}$ on the nondeprived sides $(p=0.24)$.

In contrast to these findings, the surface areal density of the synapses of both polarities on the mitral cell somata was significantly less on the deprived side (see Fig. 11). The ratio given by the number of mitral-togranule cell synapses per soma divided by the number of granule-to-mitral cell synapses per soma was 1.66 for the deprived cells and 1.18 for the nondeprived cells $(0.05<$ $p<0.10$ ). 'Thus, in addition to there being far fewer synapses of both types on the somata of mitral cells in the deprived olfactory bulbs, there appeared to be a tendency for there to be fewer of the granule-to-mitral polarity as compared with the mitral-to-granule polarity.

TABLE II

Laminar mean volumes \pm standard error in cubic millimeters for left and right control olfactory bulbs with paired t test $p$ values

\begin{tabular}{lccc}
\hline \multicolumn{1}{c}{ Lamina } & Left Control & Right Control & $p$ Values $^{a}$ \\
\hline Olfactory nerve layer & $1.16 \pm 0.058$ & $1.16 \pm 0.060$ & 0.98 \\
Glomerular layer & $1.08 \pm 0.022$ & $1.07 \pm 0.024$ & 0.97 \\
External plexiform layer & $1.23 \pm 0.451$ & $1.22 \pm 0.045$ & 0.41 \\
Mitral cell layer & $0.21 \pm 0.008$ & $0.21 \pm 0.006$ & 0.72 \\
Granule cell layer & $1.84 \pm 0.073$ & $1.80 \pm 0.076$ & 0.01 \\
Ventricular/subependymal & $0.04 \pm 0.002$ & $0.04 \pm 0.001$ & 0.22 \\
$\quad$ & & & \\
\hline
\end{tabular}

${ }^{a} \mathrm{p}$ value must be $<0.0085$ for experiment-wise $p<0.05$.

TABLE III

$p$ values of ANOVA's "litter effect" for each bulbar lamina ${ }^{a}$

\begin{tabular}{lc}
\hline \multicolumn{1}{c}{ Lamina } & $p$ \\
Olfactory nerve layer & 0.06 \\
Glomerular layer & 0.06 \\
External plexiform layer & 0.02 \\
Mitral cell layer & 0.03 \\
Granule cell layer & 0.12 \\
Ventricular/subependymal zone & 0.52 \\
\hline
\end{tabular}

${ }^{a} p$ value must be $<0.0085$ for experiment-wise $p<0.05$.

\section{Discussion \\ Olfactory epithelium}

Quantitative evaluation of nasal septal epithelia and qualitative assessment of whole nasal cavities suggests that the number of mature olfactory receptors at PN 30 is not affected by naris closure at PN 1 or 2 . The finding that neonatal naris closure does not lead to fewer olfactory receptors suggests that the effects of olfactory deprivation on the olfactory bulb at $\mathrm{PN} 30$ are not due to transneuronal degenerative phenomena (Pinching and Powell, 1971) or to an attenuation of possible inductive influences (e.g. Burr, 1916, 1930) resulting from a diminution in the number of olfactory receptors.

\section{Olfactory bulb}

Function. Deoxyglucose autoradiography at 21 and 30 postnatal days has shown that unilateral naris closure functionally deprives the developing ipsilateral olfactory bulb. The term "deprived" appears appropriate in this case because of the absence of focal deoxyglucose uptake in bulbs ipsilateral to a closed naris. Few or no foci of uptake have also been reported in the olfactory bulbs of rats exposed to pure air (Stewart et al., 1979), suggesting that in the case of naris closure, as in a pure air environment, odorant molecules are not stimulating the receptor sheet. It would seem unlikely that the observed differences in deoxyglucose uptake are due to a normal cyclic alteration in the function of the two bulbs, such as may have been observed by Stewart et al. (1979), because at two different ages, in each of two experimental animals, there was less deoxyglucose uptake on the side of naris closure.

The deoxyglucose technique has been employed for the localization and delineation of brain loci with experimentally altered functional activity consequent to sensory impairment in the auditory (Sokoloff, 1977), somatosensory (Kossut et al., 1979), visual (Kennedy et al., 1975), and olfactory (Sharp et al., 1975) systems. The present results are comparable to those in the olfactory and other systems and suggest that the olfactory bulb ipsilateral to the closed naris is deprived over the entire 30 -day experimental period.

Light microscopy. Other than the marked differences in sizes between deprived and nondeprived olfactory bulbs and their constituent layers, the differences that could be observed with Nissl-stained sections in the light microscope were not striking. The finding of size differences agrees with the reports of Gudden (1870), Meisami (1976), and Meisami and Mousavi (1981). Meisami (1978) could also detect no obvious difference in bulbar cytoarchitecture using a Nissl stain.

TABLE IV

Mitral cell and lateral olfactory tract measurements (mean $\pm S E$ )

\begin{tabular}{|c|c|c|c|}
\hline & Deprived & Nondeprived & $p$ \\
\hline Nuclear radius & $5.28 \pm 0.13 \mu \mathrm{m}^{2}$ & $5.26 \pm 0.08 \mu \mathrm{m}^{2}$ & 0.83 \\
\hline Nucleoli/nuclear profile & $1.05 \pm 0.04$ & $0.98 \pm 0.03$ & 0.20 \\
\hline Mitral cells/olfactory bulb & $37,606 \pm 781$ & $38,355 \pm 1,428$ & 0.58 \\
\hline
\end{tabular}




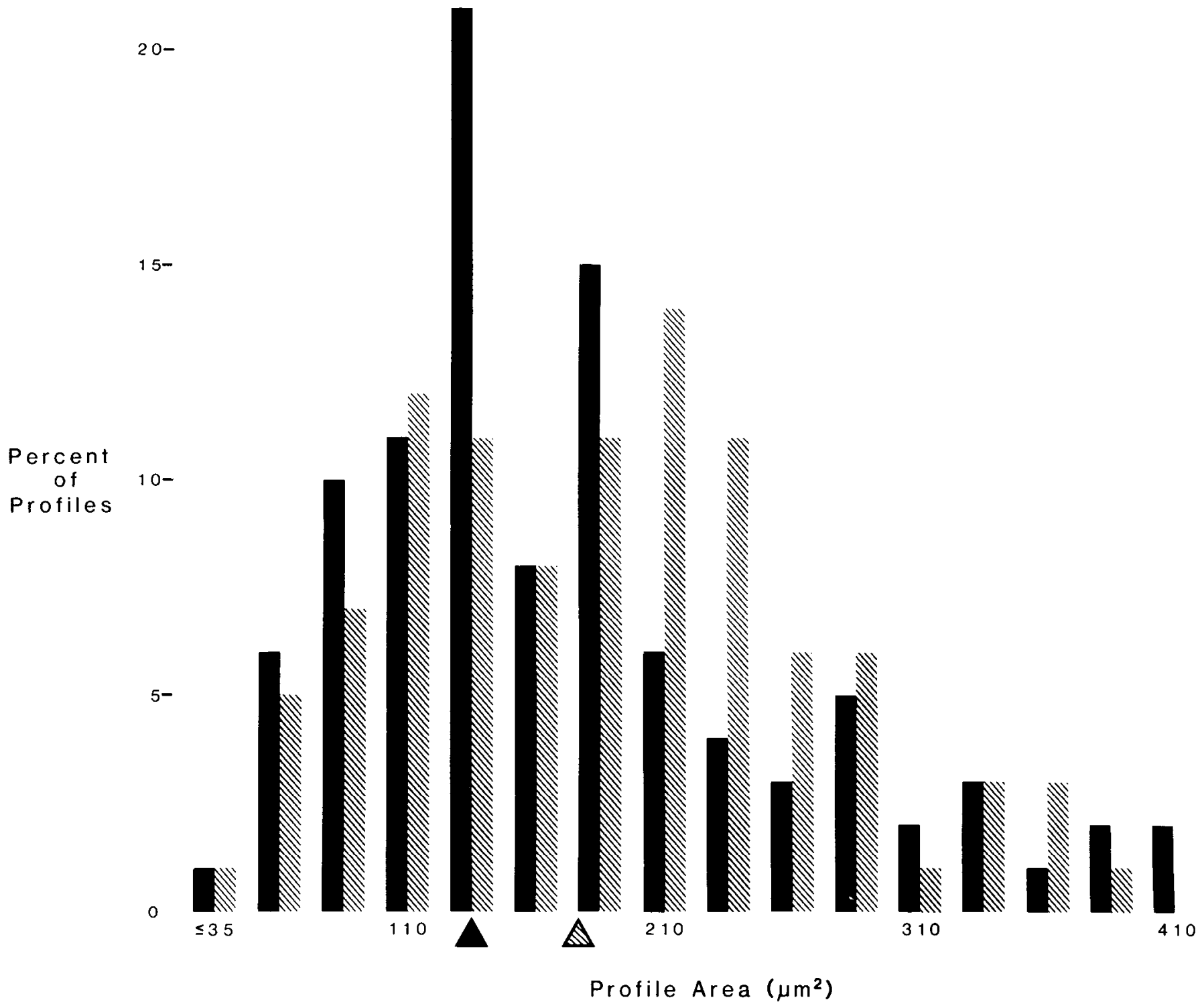

Figure 10. Distributions of mitral cell soma cross-sectional areas. Mitral cells from deprived sides are represented by black bars, those from nondeprived sides by cross-hatched bars. Note that there are relatively few large profiles in the distribution from deprived sides. The positions of the medians of these distributions are represented by the arrowheads. These two distributions are significantly different as determined by a Kolmogorov-Smirnov test $(p<0.001)$.

The present report is the first morphometric analysis of the effects of sensory deprivation on the volume of the constituent laminae of the olfactory bulb. The volumes of all bulbar laminae except for that of the ventricular/ subependymal zone are smaller on the side of naris closure, and, in addition, there is no significant hypertrophy of any bulbar lamina contralateral to the side of naris closure.

The finding that the volume of the olfactory nerve layer was significantly smaller, but not strikingly so, on the side of naris closure seems curious in light of evidence suggesting that there were the same number of receptors on that side. A number of factors probably account for the smaller volume: (1) The volume of the nerve layer occupied by the arteries and veins which must traverse it to serve the smaller olfactory bulb may have been smaller. (2) Because caudal portions of the smaller bulb are relatively rostrally situated, axons can be shorter and yet reach the same relative glomerulus as a comparable contralateral axon. (3) In addition to this reduction in length, there might be a reduction in the diameter of axons on the deprived side relative to the nondeprived side, since it has been demonstrated that nerve fibers can swell due to propagation of an impulse (Iwasa et al., 1980).

It is clear from the present analysis that the volume of the glomerular layer is smaller on the deprived side; however, the Nissl morphology of that layer is relatively normal. This would suggest that there is a smaller volume of both glomerular and periglomerular components on the deprived side, a suggestion that is contrary to reports in the rat that glomerulus size (Meisami, 1979) and number (Meisami, 1978) are no smaller on the side of naris closure. The Bodian protargol stain gave evidence 
D

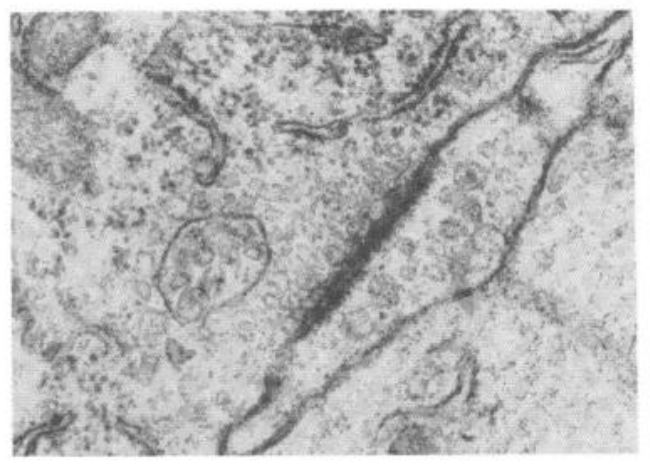

$52.5 /$ soma

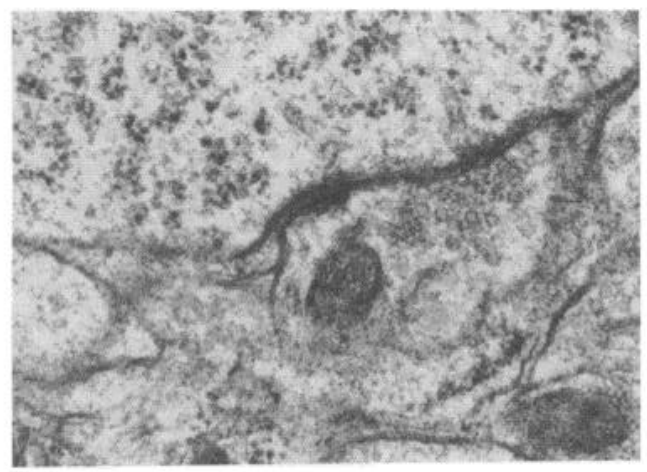

G-M

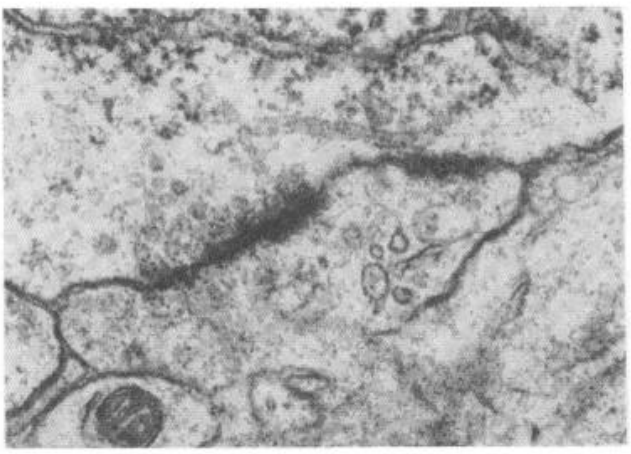

88.0/soma

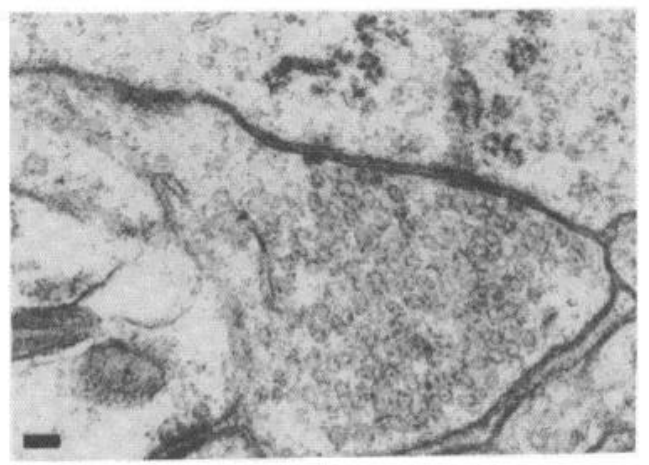

74.7/soma

\section{7/soma}

Figure 11. Examples of synapses from a deprived $(D)$ and a nondeprived $(N D)$ olfactory bulb. Both mitral-to-granule cell synapses $(M-G)$ and granule-to-mitral cell synapses $(G-M)$ are shown. The mean number of synapses of each type per soma is presented. In the paired $t$ test of M-G synapses, $p=0.0005$. In the comparison of G-M synapses, $p=0.0034$. Eighty-nanometer sections; uranyl acetate, lead citrate stain. Bar $=150 \mathrm{~nm}$ for each example.

that glomerular neuropil is affected by naris closure. With the protargol method the dense gray glomerular background, which has been reported to be absent or depleted after damage to the olfactory epithelium, and which has been attributed to the terminations of olfactory nerve fibers (Matthews and Powell, 1962), remained in the experimental animals. However, dendritic arborizations within glomeruli appeared deficient.

The smaller volume of the external plexiform layer and the normal radial disposition of mitral cell primary dendrites observed in protargol sections on the deprived side indicate that the length of these processes is shorter. It was not determined to what extent other dendrites, axons, or processes of any one cell type contributed to the smaller volume of the external plexiform layer. However, since it is likely that there are fewer granule cells in the reduced volume of the granule cell layer, there is probably a decreased volume of granule cell dendrites in the external plexiform layer.

In contrast to the loss of mitral cells which Meisami (1978) has reported in rats, there were not significantly fewer mitral cells on the closed side in the mice examined in this study. In our measurements of mitral cell perikarya from electron micrographs, it was determined that there is a smaller population of relatively large cells in deprived olfactory bulbs compared with nondeprived bulbs. Meisami (1978; Meisami and Safari, 1981) counted "all macroneurons situated on or just adjacent to the mitral cell layer," criteria which apparently have relatively large size as a component. The indistinct cytology of some paraffin-embedded mitral cells, together with a criterion for identification emphasizing relatively large size, could yield a consistent relative undercounting of mitral cells on the deprived side. It would seem that reductions in the number of mitral and tufted cells of the magnitude reported by Meisami (1978), 26 and $46 \%$, respectively, should be reflected in a significantly smaller cross-sectional area of the lateral olfactory tract on the closed side, but this was not observed in the present study. Furthermore, Meisami and Mousavi's (1981) results on the DNA content of deprived and nondeprived olfactory bulbs do not indicate a reduction between post- 
natal days 10 and 25 in the deprived bulb, but rather a reduced gain during that period which was also observed to postnatal day 270 .

An interprettion that is suggested by the results of the present work and those of Meisami and Mousavi (1981) is that mitral cells, which are generated prenatally (Hinds, 1968) and relatively mature according to cytological (Hinds, 1972; Hinds and Ruffett, 1973) and intrabulbar (Hinds and Hinds, 1976a) and extrabulbar (Hinds and Hinds, 1976a) synapse criteria by the time deprivation begins, do not degenerate by postnatal day 30 . Rather, other cells which would normally be added to the bulb during the course of the deprivation, such as periglomerular and granule cells (Hinds, 1968), may either undergo greater cell death or proliferate at a lower rate, or both (cf. Raymond et al., 1983). The observation that the ventricular/subependymal zone is not reduced in volume due to the deprivation at first sight suggests that the proliferation of these cells and their migration into this zone is not influenced by deprivation. However, another possibility is that decreased proliferation is coupled with decreased migration from the zone.

Mitral cell perikarya were significantly smaller on the deprived sides in the present study, a finding contradictory to that of Meisami and Safari (1981). As previously discussed, these researchers apparently had a criterion for the identification of mitral cells that included relative large size. Such a criterion in this case would clearly interfere with an accurate determination of mitral cell size. In the present analysis of electron micrographs, all cells in a section which had the cytological characteristics of mitral cells and which were sectioned through the nucleus were measured. Our results are in agreement with numerous reports of reduced perikaryal size or a reduction in relative perikaryal growth in cases of visual (Wiesel and Hubel, 1963; Kalil, 1980) and auditory (Coleman and O'Connor, 1979; Webster and Webster, 1979) deprivation or impairment.

Electron microscopy. The surface areal density of synapses from and onto the somata of mitral cells was found to be low on the closed side as compared with the open side at PN 30. The finding that synapse lengths were not significantly altered by the manipulation suggests that this result was not due to undercounting, which might have occurred, for example, if synapse lengths were shorter on the deprived side. Undercounting of granuleto-mitral cell synapses may have occurred because these symmetrical synapses are less obvious than the asymmetrical mitral-to-granule cell synapses, but counting directly from the electron microscope negative at high magnification probably kept such undercounting to a minimum. Undercounting due to tangential sectioning (Hinds and McNelly, 1979) was minimized by using only mitral cell somata with visible nuclear profiles. In most cases, the plasma membrane of such cells was sectioned nearly perpendicularly. Even if some undercounting did occur, it would be expected that it would occur to the same extent for both the deprived and nondeprived olfactory bulbs.

Quantitative analysis of synapses in the normal developing mouse olfactory bulb has indicated that the total numbers of mitral-to-granule cell and granule-to-mitral cell synapses in the external plexiform layer increase substantially over the period during which deprivation took place in the present study (Hinds and Hinds, 1976a). Hinds and McNelly (1979) have demonstrated that in the rat the numbers of somato-dendritic mitral-to-granule synapses increase significantly from 3 to 27 months. In light of these findings, the present results suggest that olfactory deprivation interferes with the formation or maturation of synapses. A similar effect has been observed in the superior colliculus of rats (Lund and Lund, 1972) and in the visual cortex of cats (Winfield, 1981) and rabbits (Müller et al., 1981) after bilateral deprivation or patterned vision impairment.

The criteria that were used for synapse counting in the present analysis would have selected for synapses that are "mature" by the criteria of Hamori (1980) or Jones (1981). Thus, it is conceivable that the rate of synapse maturation was slowed by deprivation, although this was not specifically studied. It would be relatively straightforward, using the type of analysis employed by Hinds and Hinds $(1976 a, b)$, to determine what aspects of synapse maturation, if any, are affected by deprivation.

The ratio given by the number of somatic mitral-togranule cell synapses divided by the number of somatic granule-to-mitral cell synapses appears to be higher on the closed side. This suggests that for every mitral-togranule cell synapse that has formed on the deprived side, fewer granule-to-mitral cell synapses have formed than on the nondeprived side. It has been reported that in normal material the ratio of these two types of synapses is nearly 1:1 (Jackowski et al., 1978), but serial section electron microscopic analysis in the mouse has indicated that while a synapse from a granule cell gemmule is invariably paired with a synapse from a mitral cell, the converse is not always the case (Hinds and Hinds, 1976a). Furthermore, this latter study has presented evidence which suggests that the mitral-to-granule component of the reciprocal synapse forms before its reciprocal partner. In light of these reports, the present study suggests that activity in the mitral-to-granule cell synapse is one of the factors that may lead to the formation of a reciprocal granule-to-mitral cell synapse.

There is substantial evidence that the asymmetrical mitral-to-granule cell synapse is excitatory whereas the symmetrical granule-to-mitral cell synapse is inhibitory (e.g., Rall et al., 1966; Rall and Shepherd, 1968; Jahr and Nicoll, 1980). Studies on the visual system have given results similar to those in the present report in that the ratio of asymmetrical to symmetrical synapses increased due to neonatal visual impairment (Lund and Lund, 1972; Winfield, 1981), but in the visual system the excitatory or inhibitory nature of the synapses is not so firmly established. In addition, due to neuropil complexity, the identity of the neural elements from which the synapses arose was not established in the visual system studies. In the present case it is clear that sensory deprivation affects the development of the synapses of a specific projection or Golgi type I neuron, the mitral cell, and probably to a greater extent the synapses of a specific interneuron, the granule cell, with which the mitral cell is in reciprocal synaptic relation.

The present results indicate that effects of olfactory deprivation as measured at PN 30 are due not to the loss of major projection neurons but, among other things, to 
decreased dendritic elaboration by olfactory bulb neurons, and a decrease in the formation of reciprocal synapses.

In summary, neonatal naris closure functionally deprives the ipsilateral olfactory bulb without obvious damage to olfactory receptors. Except for the ventricular/ subependymal zone, the volume of each lamina in the deprived olfactory bulb is small relative to the volume of contralateral and control laminae. The number of mitral cells is not affected by deprivation, but the somata of these cells are. It is proposed that postnatally, but probably not prenatally generated cells undergo cell death at an accelerated rate and/or proliferate at a reduced rate because of the deprivation. Finally, there are fewer mitral-to-granule and granule-to-mitral cell synapses on the mitral cell somata of the deprived side, and the formation of the latter inhibitory synapses is apparently more affected than that of the former excitatory synapses: This suggests that olfactory sensation plays an important role in the formation of reciprocal synapses in the olfactory bulb.

\section{References}

Bodian, D. (1936) A new method for staining nerve fibers and nerve endings in mounted paraffin sections. Anat. Rec. 65: 89-97.

Burr, H. S. (1916) The effects of the removal of the nasal pits in Amblystoma embryos. J. Exp. Zool. 20: 27-57.

Burr, H. S. (1930) Hyperplasia in the brain of Amblystoma. J. Exp. Zool. 55: 171-191.

Coleman, J. R., and P. O'Connor (1979) Effects of monaural and binaural sound deprivation on cell development in the anteroventral cochlear nucleus of rats. Exp. Neurol. 64: 553566.

Floderus, S. (1944) Untersuchungen über den Bau der menschlichen Hypophyse mit besonderer Beruchsichtigung der quantitativen mikromorphologischen Verhaltnisse. Acta Pathol. Microbiol. Scand. 53: (Suppl.) 1-276.

Freedman, L. S. (1974) A note on Aherne's method of counting tissue components in relatively thick sections. J. Microsc. 100: $219-225$.

Frühwald, V. (1935) Die Folgen des einseitigen Nasenversuchlusses auf die Riechschleimhaut und auf den Bulbus und Tractus olfactorius. Arch. Ohren-, Nasen- Kehlkopfh. 139: 153-173.

Graziadei, P. P. C., and G. A. Monti Graziadei (1979) Neurogenesis and neuron regeneration in the olfactory system of mammals. I. Morphological aspects of differentiation and structural organization of the olfactory sensory neurons. J. Neurocytol. 8: 1-18.

Gudden, B. (1870) Experimentaluntersuchungen über das Peripherische und centrale Nervensystem. Arch. Psychiatr. (Berlin) 2: 693-723.

Haberly, L. B., and J. L. Price (1977) The axonal projection patterns of the mitral and tufted cells of the olfactory bulb in the rat. Brain Res. 129: 152-157.

Hamori, J. (1980) Plasticity during neuronal differentiation: An experimental morphological study of developing synapses and of neuronal networks. In Neurobiological Basis of Learning and Memory, Y. Tsukada and B. W. Agranoff, eds., pp. 1-18, John Wiley \& Sons, New York.

Hand, P. H. (1979) Patel-Hand counterstaining of $20 \mu \mathrm{m} \mathrm{2-DG}$ sections. In Neuroanatomical Techniques, E. G. Jones, organizer, p. 177, Society for Neuroscience, Bethesda, MD.

Hinds, J. W. (1968) Autoradiographic study of histogenesis in the mouse olfactory bulb. I. Time of origin of neurons and neuroglia. J. Comp. Neurol. 134: 287-304.

Hinds, J. W. (1972) Early neuron differentiation in the mouse olfactory bulb. I. Light microscopy. J. Comp. Neurol. 146; 233-252.

Hinds, J. W., and P. L. Hinds (1976a) Synapse formation in the mouse olfactory bulb. I. Quantitative studies. J. Comp. Neurol. 169: 15-40.

Hinds, J. W., and P. L. Hinds (1976b) Synapse formation in the mouse olfactory bulb. II. Morphogenesis. J. Comp. Neurol. 169: 41-62.

Hinds, J. W., and N. A. McNelly (1977) Aging of the rat olfactory bulb: Growth and atrophy of constituent layers and changes in size and number of mitral cells. J. Comp. Neurol. 171: $345-368$.

Hinds, J. W., and N. A. McNelly (1979) Aging in the rat olfactory bulb: Quantitative changes in mitral cell organelles and somato-dendritic synapses. J. Comp. Neurol. 184: 811820.

Hinds, J. W., and T. L. Ruffett (1973) Mitral cell development in the mouse olfactory bulb: Reorientation of the perikaryon and maturation of the axon initial segment. J. Comp. Neurol. 151: 281-306.

Iwasa, K., I. Tasaki, and R. C. Gibbons (1980) Swelling of nerve fibers associated with action potentials. Science 210 : 338-339.

Jackowski, A., J. G. Parnavelas, and A. R. Lieberman (1978) The reciprocal synapse in the external plexiform layer of the mammalian olfactory bulb. Brain Res. 159: 17-28.

Jahr, C. E., and R. A. Nicoll (1980) Dendroendritic inhibition: Demonstration with intracellular recording. Science 207 : 1473-1475.

Jones, D. G. (1981) Quantitative analysis of synaptic morphology. Trends Neurosci. 4: 15-17.

Kalil, R. (1980) A quantitative study of the effects of monocular enucleation and deprivation on cell growth in the dorsal lateral geniculate nucleus of the cat. J. Comp. Neurol. 189: 483-524.

Kennedy, C., M. H. Des Rosiers, J. W. Jehle, M. Reivich, F. R. Sharp, and L. Sokoloff (1975) Mapping of functional neural pathways by autoradiographic survey of local metabolic rate with $\left[{ }^{14} \mathrm{C}\right]$ deoxyglucose. Science $187: 850-853$.

Kerjaschki, D., and H. Hörandner (1976) The development of mouse olfactory vesicles and their cell contacts: A freezeetching study. J. Ultrastruct. Res. 54: 420-444.

Kossut, M., P. Hand, J. Greenberg, A. Sylvestro, C. Goochee, and M. Reivich (1979) Plasticity of a somatosensory cortical column: A comparison of the effects of neonatal and adult receptor ablations in the rat using the $\left[{ }^{14} \mathrm{C}\right]$-2-deoxyglucose technique. Soc. Neurosci. Abstr. 5: 630.

Lund, J. S., and R. D. Lund (1972) The effects of varying periods of visual deprivation on synaptogenesis in the superior colliculus of the rat. Brain Res. 42: 21-32.

Matthews, M. R., and T. P. S. Powell (1962) Some observations on transneuronal cell degeneration in the olfactory bulb of the rabbit. J. Anat. 96: 89-105.

Mayhew, T. M. (1979) Stereological approach to the study of synapse morphometry with particular regard to estimating number in a volume and on a surface. J. Neuroctyol. 8: 121138.

Meisami, E. (1976) Effects of olfactory deprivation on postnatal growth of the rat olfactory bulb utilizing a new method for production of neonatal unilateral anosmia. Brain Res. 107: 437-444.

Meisami, E. (1978) Influence of early anosmia on the developing olfactory bulb. Prog. Brain Res. 48: 211-230.

Meisami, E. (1979) The developing rat olfactory bulb: Prospects of a new model system in developmental neurobiology. In 
Neural Growth and Differentiation, E. Meisami and M. A. B. Brazier, eds., pp. 183-206, Raven Press, New York.

Meisami, E., and R. Mousavi (1981) Lasting effects of early olfactory deprivation on the growth, DNA, RNA and protein content, and Na-K-ATPase and AchE activity of the rat olfactory bulb. Dev. Brain Res. 2: 217-229.

Meisami, E., and L. Safari (1981) A quantitative study of the effects of early unilateral olfactory deprivation on the number and distribution of mitral and tufted cells and of glomeruli in the rat olfactory bulb. Brain Res. 221: 81-107.

Monti Graziadei, G. A., R. S. Stanley, and P. P. C. Graziadei (1980) The olfactory marker protein in the olfactory system of the mouse during development. Neuroscience 5: 12391252 .

Müller, L., A Pattiselanno, and G. Vrensen (1981) The postnatal development of the presynaptic grid in the visual cortex of rabbits and the effect of dark-rearing. Brain Res. 205: 3948.

Peters, A. (1970) The fixation of central nervous tissue and the analysis of electron micrographs of the neuropil, with special reference to the cerebral cortex. In Contemporary Research Methods in Neuroanatomy, W. J. H. Nauta and S. O. E. Ebbesson, eds., pp. 56-76, Springer-Verlag, New York.

Pinching, A. J., and T. P. S. Powell (1971) Ultrastructural features of transneuronal cell degeneration in the olfactory system. J. Cell Sci. 8: 253-287.

Price, J. L., and T. P. S. Powell (1970) The mitral and short axon cells of the olfactory bulb. J. Cell Sci. 7: 631-651.

Price, J. L., and W. W. Sprich (1975) Observations on the lateral olfactory tract of the rat. J. Comp. Neurol. 162: 321336.

Rall, W., and G. M. Shepherd (1968) Theoretical reconstruction of field potentials and dendrodendritic synaptic interactions in olfactory bulb. J. Neurophysiol. 31: 884-915.

Rall, W., G. M. Shepherd, T. S. Reese, and M. W. Brightman (1966) Dendrodendritic synaptic pathway for inhibition in the olfactory bulb. Exp. Neurol. 14: 44-56.

Ramón y Cajal, S. R. (1911) Histologie du Système Nerveux de l'Homme et des Vertébrés, Vol. II, pp. 647-674, Maloine, Paris. (Reprinted (1955) by Consejo Superior de Investigaciones Cientificas, Madrid.)

Raymond, P. A., S. S. Easter, Jr., J. A. Burnham, and M. K. Powers (1983) Postembryonic growth of the optic tectum in goldfish. II. Modulation of cell proliferation by retinal fiber input. J. Neurosci. 3: 1092-1099.

Schneider, S. P., J. W. Scott, and E. Orona (1982) Intracellular filling of mitral and tufted cells with horseradish peroxidase confirms their identification by antidromic activation. Association for Chemoreception Sciences, Fourth Annual Meeting Abstracts, p. 24.

Scott, J. W. (1981) Electrophysiological identification of mitral and tufted cells and distributions of their axons in olfactory system of the rat. J. Neurophysiol. 46: 918-931.

Sharp, F. R., J. S. Kauer, and G. M. Shepherd (1975) Local sites of activity-related glucose metabolism in rat olfactory bulb during olfactory stimulation. Brain Res. 98: 596-600.

Smith, C. G. (1935) The changes in volume of the olfactory and accessory olfactory bulbs of the albino rat during postnatal life. J. Comp. Neurol. 61: 477-508.

Smith, C. G. (1937) Pathologic change in olfactory nasal mucosa of albino rats with "stunted" olfactory bulbs. Arch. Otolaryngol. 35: 131-143.

Sokal, R. R., and F. J. Rohlf (1969) Biometry, pp. 601-607, W. H. Freeman and Co., San Francisco.

Sokoloff, L. (1977) Relation between physiological function and energy metabolism in the central nervous system. J. Neurochem. 29: 13-26.

Steel, R. G. D. (1961) Query 163: Error rates in multiple comparisons. Biometrics 17: 327-328.

Stewart, W. B., J. S. Kauer, and G. M. Shepherd (1979) Functional organization of rat olfactory bulh analyzed by the 2-deoxyglucose method. J. Comp. Neurol. 185: 715-734.

Stryker, M. P. (1979) Protocol for qualitative use of Sokoloff's 2-deoxyglucose autoradiographic method for determining local rates of glucose utilization in neural tissue. In Neuroanatomical Techniques, E. G. Jones, organizer, pp. 171-176, Society for Neuroscience, Bethesda, MD.

Webster, D. G., and Webster, M. (1979) Effects of neonatal conductive hearing loss on brain slem auditory nuclei. Ann. Otol. Rhinol. Laryngol. 88: 684-688.

Wiesel, T. N., and D. H. Hubel (1963) Effects of visual deprivation on morphology and physiology of cells in the cat's lateral geniculate body. J. Neurophysiol. 26: 978-993.

Winer, B. J. (1962) Statistical Principles in Experimental Design, McGraw-Hill, New York.

Winfield, D. A. (1981) The postnatal development of synapses in the visual cortex of the cat and the effects of eyelid closure. Brain Res. 206: 166-171. 